\title{
A PHILOLOGICAL INVESTIGATION OF THE OLD UYGHUR PILGRIM INSCRIPTIONS RECENTLY DISCOVERED IN THE CAVE NK 10 IN THE TUYOQ GROTTOES OF TURFAN
}

\author{
ABDURISHID YAKUP* AND LI XIAO** \\ *School of Chinese Ethnic Minority Languages and Literatures of Minzu University of China \\ Zhongguancun South Avenue, Haidian District, Beijing, 100081, P. R. China; \\ Berlin Brandenburg Academy of Sciences and Humanities, Turfanforschung \\ Jägerstraße 22-23, Berlin 10117, Germany \\ e-mail: yakup@bbaw.de \\ ${ }^{* *}$ School of Chinese Classics, Renmin University of China \\ Zhongguancun Great Avenue 58, Haidian District, Beijing, 100872, P. R. China \\ e-mail: haidaoqi@aliyun.com
}

\begin{abstract}
Among the discoveries of excavations carried out by a joint team of Chinese archaeologists between the autumn of 2010 and the early summer of 2011 in the Tuyoq Grottoes in Turfan, 22 pilgrim inscriptions in Old Uyghur script were found in the Northern Cave 10 (NK 10). All of them are notes made by Buddhists who made a pilgrimage to the cave. Although the photo of these inscriptions has been published twice in recent years, an edition of them is still missing. This paper presents results of philological investigation on 20 of these pilgrim inscriptions. One inscription is briefly discussed in the general description as its structure is difficult to recognise, whereas an edition of another inscription, the one on the upper side of the left wall, is reserved for further research, as the inscription is not clearly visible in the available photo.
\end{abstract}

Key words: Old Uyghur, pilgrim inscriptions, the Tuyoq Grottoes, the Northern Cave 10, Turfan, philological investigation.

\section{Introduction}

Pilgrim inscriptions constitute a special corpus of Old Uyghur Buddhist literature, showing a special structure and wording. The majority of them are notes made by literate Buddhists on the wall of Buddhist monasteries, stūpas, and temples, who made a pilgrimage to or visited them as holy Buddhist places. There are also some pilgrim inscriptions left by visitors with Christian and Muslim names; however, their number is fairly limited (see Bai and Matsui 2016: 49-53; Matsui 2017: 7-8). Certain number of pilgrim inscriptions in Old Uyghur were discovered and already published in the early phase of French excavations in Dunhuang, and during the four German excavations in Kucha and Turfan which were carried out in the first decade of the 20th 
century. Some of them have been re-edited later. ${ }^{1}$ An early edition of the Old Uyghur wall inscriptions from the Yulin 榆林 caves near Dunhuang was published in Hamilton and Niu (1998). Porció (2014) and Matsui (2017) review the general state of wall inscriptions in Old Uyghur and the history of their research in detail, I refrain from discussing it here in detail. It should be noted that Porció (2014) and Matsui (2017) do not mention the inscriptions discovered in the Northern Cave 10 in the Tuyoq Grottoes. As Matsui (2017: 6) points out, Porció's discussions are based on the publications that appeared before 2014. Research on Old Uyghur inscriptions, including pilgrim inscriptions has made considerable progress in the last four years. Matsui (2015) presents results of research on the Old Uyghur inscriptions discovered in the Mogao caves in Dunhuang and in the Yulin caves in Anxi 安西. Bai Yudong 白玉冬 and Matsui Dai (2016) published inscriptions found in the White Pagoda (Chin. 白塔 Baita) in Hohhot, paying special attention to analysis on the pilgrim groups and visitors with Christian and Muslim names, including their religious activities reflected in the Old Uyghur inscriptions. Matsui's edition of the Old Uyghur and Mongol inscriptions of the Dunhuang Grottoes (see Matsui 2017) is the most comprehensive investigation of these inscriptions discovered in various Buddhist caves in and around Dunhuang, including a large number of pilgrim inscriptions. It presents an edition or reedition of 283 inscriptions in various scripts, e.g. 'Phags-pa, traditional Mongolian alphabet (Uyghur-Mongolian script), and Old Uyghur script. Each section comprises brief information on the state of preservation and research, a transcription, a Japanese translation and a brief commentary together with a list of Old Uyghur and Mongolian words. Another list comprises personal names occurring in the inscriptions.

The language of some inscriptions in Brāhmī script edited in Kitsudō 橘堂 (2017) is Old Uyghur, some of them are known from Dieter Maue's catalogues of Old Uyghur texts written in Brāhmī script (see Maue 1996: Nos. 72-77; Maue 2015: Nos. 210-213). They are also an important source for studies on Old Uyghur pilgrim inscriptions.

The present paper reports the results of the primary philological investigation of the pilgrim inscriptions newly discovered in the NK 10 in Tuyoq, mainly based on photos made by Li Xiao 李肖, the former director of Turfan Museum and Former First Deputy Director of Turfan Academy, during our joint visit to the Tuyoq caves in September 2011, and the notes made by A. Yakup during and soon after the visit to the Tuyoq caves.

\section{On the Pilgrim Inscription Discovered in the Cave NK 10 in Tuyoq}

In a general survey of the excavations jointly carried out by the Archaeological Institute of Chinese Academy of Social Sciences, Turfan Academy, and Kucha Academy in the northern portions of the western zone of the Tuyoq Grottoes in Turfan between

\footnotetext{
${ }^{1}$ Mainly see von Le Coq 1913: 33-34; von Le Coq 1922-1926; Pelliot 1922-1924; Pelliot et al. 1981-1992; Kara 1976; Zieme 1985: 189-192; Matsui 2008. 
the autumn of 2010 and early summer of 2011, it is reported that on the niche of the central part of the back wall of the cave NK 10 there is a large number of Old Uyghur inscriptions in black ink, and the western wall of the same cave not only contains Old Uyghur inscriptions in black ink, but also has several lines of Chinese inscriptions in red ink (Chen et al. 2012b: 20). In the same paper, a photo of some wall inscriptions on the western wall was published. Later, a clearer photo of the same wall inscriptions together with another two photos of the wall inscriptions of the same cave were published by Li Xiao 李肖 (Chen et al. 2012b, Plate 11, Photo 3; Li 2015: 155 [Photos 47-49], 152 [Photo 33]). Clearly, this is only a part of the wall inscriptions discovered during the afore-mentioned excavations, together with a considerable number of wall paintings, wooden frames, wood pens, and texts in various scripts, including Brāhmī, Chinese, Old Uyghur, Sogdian, and Tibetan. Three reports jointly prepared by Chen Ling 陈凌, Li Yuqun 李裕群 and Li Xiao 李肖 present a primary survey on these excavations (see Li et al. 2011; Chen et al. 2012a and 2012b). Brief information on the hitherto published Old Uyghur texts discovered during these excavations was given by Yakup and $\mathrm{Li}$ (2018).

Of the 22 pilgrim inscriptions in the cave NK 10, only one inscription has survived. It consists of three lines, and was written on the upper side of the left wall. Unfortunately, the inscription is not clear enough to be readable in the photo currently available. It requires a special photo made through a new photographing technique to decipher it, thus we temporarily exclude its edition in this paper. There is another text comprising some words just above Inscription B edited below. It might be read as follows:

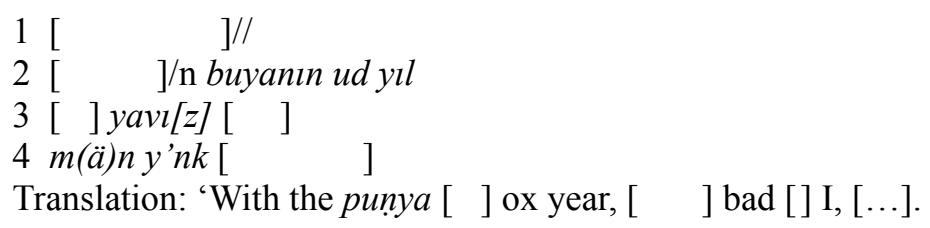

This should be the last part of an inscription. However, its structure is not clearly recognisable from the text remaining. We also do not consult it in the edition below. There are some isolated letters or signs on the back wall; however, their function and relation to the texts on the wall is not clear, thus we do not take them into consideration either.

From the six inscriptions, namely Inscriptions A, J, P, Q, R, T, only a very limited number of words have survived. However, their structure and some phrases are clearly recognisable, therefore, we include them in the transcription and translation, providing notes when necessary.

Inscription B is a memory made by two persons, Turmıš Tutung, presumably an official, and the monk [Taš]vardu. The name of the latter occurs again in the same form in Inscription I. Interestingly, the first one, Turmıš Tutung, uses the verb biti'to write', whereas the second one, [Taš] vardu, uses čiz- 'to draw'. The use of čizimplies that somewhere else in the text there are some signs or images. The word $v u$ 
'sign' appearing with some distance to the main text might be part of that sign or image. This shows that in the inscriptions in cave NK 10, the verb biti- 'to write' refers to 'to compose a text', whilst čiz- 'to draw' is used to refer to 'to sign' or 'to paint of an image'. This is especially obvious in Inscriptions $\mathrm{H}$, I, and $\mathrm{K}$, which will be discussed below.

The writer's name in Inscription $\mathrm{C}$ and Inscription $\mathrm{D}$ is not completely preserved, however, both inscriptions contain the expressions ötig qll- 'to leave of record', or 'to leave a memory', and ötig bolup t[u]rz[u]n 'May it be kept as a memory', clearly implying that these are notes made for people in the future. Inscription $\mathrm{D}$ has another interesting expression, which we read öginmäktä bolmazun 'One should not boast about (this)'. A similar expression is also known from an inscription discovered in the second cave of the Eastern Grottoes of Dunhuang, e.g. qaqımiš (bolma)zun 'They should not abuse' (Matsui 2017: 136).

At the end of lines $04-09$ of Inscription E, there is an image, perhaps of a temple decorated with a lotus in the centre as well as a decoration on the top and another image on the right side. The connection of the text to the image is not clear. The text is written by a person called Qod $\gamma \mathrm{u}$, and the same name also occurs in Inscription G, but together with a component or a title Tutung. Presumably, Qod $\gamma$ u found in Inscriptions $\mathrm{E}$ and $\mathrm{G}$ represents the same person. Nevertheless, both inscriptions are written one after the other, and the ductus is also very similar.

Inscription $\mathrm{H}$ is interesting, in which we find ' $<$ ' as a sign. The same sign and two images also occur in Inscription $\mathrm{K}$ as signs. Judging from this, the images occurring directly after some texts, at least some of them, presumably had the function of a sign or an amulet (Old Uyghur vuu originating from Chin. $f u$ 符 'sign', 'mark') of some visitors. The same is also observed in Inscription I, in which the name of Jivasū Šli (his name also occurs in Inscription $O$ in a slightly different form) first appears as the composer of the text, and later also as the drawer of the image. Judging from the word lab, which was written inside the image, his sign or amulet might be a candle. We assume that $l a b$ occurring here originates from the Middle Mongolian lab 'candle'. However, use of specific letters or images as a sign or amulet of a specific visitor in this form is not known from hitherto published Old Uyghur pilgrim inscriptions.

Inscription K should have been written by a person called Senqo(?) on behalf of three monks who were staying in the temple Longfutan. The text states that Senqo(?) has written it by hearing, indicating Senqo(?) is only a scribe. Another person whose name might be read Itäguy or Itagui also claims that he has left the memory, and obviously he is another scribe who wished to leave his name among the memories of visitors. Most importantly, Inscription K mentions the place name Longfutan (Old Uyghur: luu vu tam), which we understand as the name of a temple. Presumably, it goes back to Chin. Longfutan 龍府壇 or Longfunan 龍府南. However, an exact determination of its etymology and location deserves further research. 


\section{Edition of the Pilgrim Inscriptions in NK 10}

In the edition below, the inscriptions are arranged and numbered according to their place, from left to right: first the inscription on the top and then the one at the bottom.

\subsection{Inscription $A$}

\section{Transcription}

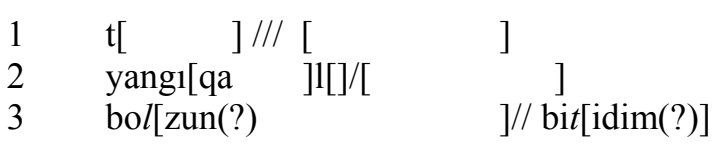

\section{Translation}

$\begin{array}{ll}1 & {[\ldots \ldots} \\ 2 & {[\text { on the }[]} \\ 3 & \text { May }[] \text { day }[\text { be }[\end{array}$

\subsection{Inscription B}

\section{Transcription}

1 bars yılın ikinti ay on yangıqa

2 udmıš quluṭı bäg turmıš tutung m(ä)n

3 bițitim körgü ödig

4 [bolzun?] čin ol m(ä)n

$5 \quad$ [Ta]švardu biž[1] m(ä)n čiztim

\section{Translation}

1 Tiger year, second month, on the 10th day,

2 I, the master Turmıš Tutung, the slave of Udmıš,

3 wrote. [May this be(?)] a memory to see.

4 (This) is true. I,

5 the monk [Ta]švardu, draw (it).

\section{Commentary}

B1 bars yllın: might be translated 'within the Tiger year', or 'in the Tiger year'. This phrase occurs as the correction of bars yll 'Tiger year' on the right side of the line. To add instrumental ending after $y l l$ 'year' is not known from Old Uyghur wall inscriptions; see, for instance, Inscription $\mathrm{K}$, line 1. 
B2 Udmiš quluṭı bäg Turmıš Tutung: might be translated 'the master Turmıš Tutung, the slave of Udmıš', the personal name $U d m i \check{s}$ is formed on the basis of the verb $u d$ - 'to follow' by means of the past participle $-m I \check{s}$, and means 'follower'. This name is also known from the documents Mi20-4 and Sa11-26 edited in Yamada 1993 (henceforth SUK). However, in SUK 297 it was considered the same name as Utmiš occurring in Mi28-9, which is derived from $u t$ - 'to win'. Although dental confusion is common in late Old Uyghur texts, $U d m i \check{s}$ 'follower' and Utmiš 'winner' might be two different names. Turmiš Tutung is another personal name and comprises the common personal name Turmiš and the title Tutung originating from Chin. Dutong 都統, which often occurs as part of personal names. For Tutung, see Oda 1987: 61-63, 67, 73; Moriyasu 2008: 207-210.

B5 [Taš]vardu biž [l]: might be translated 'the monk Tašvardu', the first three letters of this personal name were reconstructed on the basis of the same name occurring in Inscription I (I3) where it is completely preserved. This personal name, that is $[T a \check{s}]$ vardu, might also be identical to the personal name $T(a) \check{s} v(a) r d$ which was read Tšırd in SUK, Mi09-7, and might be considered a corrupted form of Tašvardu. The other component of the name, biž [l], is also known as part of a personal name in some Old Uyghur texts; for details, see Zieme 1987: 273-274. Presumably, it goes back to Chin. pi ni 毘尼, as Matsui suggested (for details, see Matsui and Arakawa 2017: 142). However, the etymology of [Taš] vardu is not completely clear, though $d u$ occurring at the end of the name might be connected to Chin. $n u$ 奴 'slave', or might also be considered the abbreviation of Tutung.

\subsection{Inscription $C$}

\section{Transcription}

1 tiši(?) tavišyan yıl ikinti ay on yangıqa

$2 \quad[\quad m(\ddot{a}) n$ ]širi öṭig q1ltım

\section{Translation}

1 Female rabbit year, second month, on the 10th day,

$2[\mathrm{I}$, ] širi made the record.

\section{Commentary}

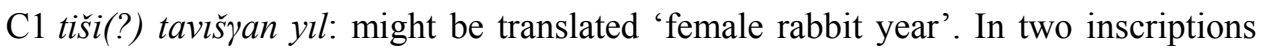
from the Yulin caves we find irkäk tavišyan yıl 'male rabbit year', which presumably translates Chin. yang tunian 陽兔年 'male rabbit year'; see Matsui and Arakawa 2017: 62, 103-104. Presumably, tiši(?) tavišyan yıl is a phrase translating another Chinese expression 陰兔年 yin tunian 'female rabbit year'. It is worth noting that, in the Tibetan calendar, there is yang shui tunian 陽水 
兔年 ‘male-water-rabbit year’ and yin jin tunian 陰金兔年 ‘female-iron-rabbit year'. However, the reading of the first word tiši is not certain.

\subsection{Inscription D}

\section{Transcription}

1 luu y1l ikinti ay yi[t]i

$2 \quad \mathrm{y}(\mathrm{e})$ girmikä bütgün quluṭ basa

$3 /[$ ] //n avar(?) bitidim öțig bolup

$4 \mathrm{t}[\mathrm{u}] \mathrm{rz}[\mathrm{u}] \mathrm{n}$ öginmäktä bolmazun

\section{Translation}

1 Dragon year, second month, on the 17th day,

2 (I), Basa /[ ] //n avar(?), the slave of Bütgün,

3 wrote. May it be kept as a memory!

$4 \quad$ One should not boast about (this)!

\section{Commentary}

D2 bütgün qulutı basa /[ ] //n avar(?): as a personal name, bütgün presumably goes back to Mongolian büdügün 'large, huge, big', though it might also be considered a noun derived from büt- 'to complete' by means of $-g X n$. For Mongolian büdügün, see Rybatzki 2006: 198. basa is part of another personal name. However, from the further part of the name only some letters are visible.

D4 öginmäktä bolmazun: might be translated 'One should not boast about (this)', 'This should not be overstated'. In this interpretation, we take ögin- as another spelling of ögün- 'to praise oneself, to boast'; for ögün-, see Clauson 1972: 110b-111a, Erdal 1991: 609.

\subsection{Inscription $E$}

\section{Transcription}

\begin{tabular}{|c|c|c|}
\hline $\begin{array}{l}01 \\
02\end{array}$ & $\begin{array}{c}\text { ] y1l ikinti ay üč y(e)\& } \\
{[/ / / \mathrm{v} / \mathrm{y} /}\end{array}$ & $\mathrm{i}[\mathrm{kä}]$ \\
\hline 03 & ay nay yingaq & bititim(?) \\
\hline 04 & Jwr qar & IMAGE \\
\hline 05 & öṭig bolzun & IMAGE \\
\hline 06 & ] brahman- & IMAGE \\
\hline 07 & [ta äšidip tu]rup(?) bitiyü & IMAGE \\
\hline 08 & [tägintim] tep män qod $\gamma \mathrm{u}$ & IMAGE \\
\hline 0 & [öțig q]1ldım körgü & IMAGE \\
\hline & bolzun ä]dgü & \\
\hline
\end{tabular}




\section{Translation}

$01 \quad[\ldots]$ year, second month, [on] the 13th day,

$02 \quad[\ldots \quad]$

03 [ ] Aynay direction(?)

04 [ ] temple(?)

05 May it be a memory.

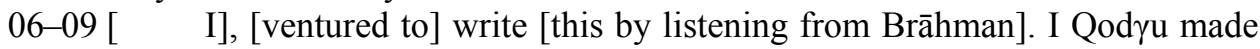
[the memory, may it] be seen.

10 Good!

\section{Commentary}

E03 ay nay: Might also be read naynay, seems to be a place name, presumably the place where the temple is located. Unfortunately, I have no explanation for either its etymology or its location.

E04 [ ]wr qar: perhaps, the last word might be reconstructed as [b] urqar 'temple' originating from Skt. vihāra via the intermediary of Sogdian $\beta r y$ ' $r$, but it is not certain. This word usually occurs in the form of vrxar, however, in some pilgrim inscriptions, we also find the form buqar or buxar; see Matsui 2017: $142-143$.

E06 brahman: should be part of a personal name and goes back to Skt. brāhman or brāhmana.

E08 qod 7 : personal name, also occurs in Inscription G, line 5, as part of the name Qodju Tutung. It is not completely clear whether both names refer to the same person.

\subsection{Inscription $F$}

\section{Transcription}

1 [ ]// y1l ikinti ay

2 on yangıqa ymä biz

3 yalngar(?) taxar(?) šiladu šusa(?)

4 bitiyü tägintim(i)z kö[rgü] öțig

5 sadu sadu ädgü ädgü bo[lzu]n

\section{Translation}

1 [ ] year, second month,

2 on the tenth day, again we,

3 Yalngar Tahar and Šiladu Šusa(?),

4 ventured to write (this). May this be a memory to see.

5 Sādhu! Sādhu! May it be good, good! [ ]. 


\section{Commentary}

F3 Yalngar Tahar(?): seems to be a personal name, however, the reading of both words is not secured.

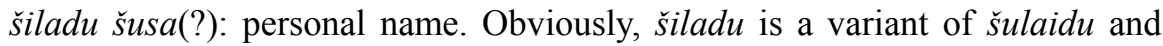
goes back to Chin. rulai $n u$ 如来奴 'slave of the Tathāgatha'. It also occurs in the same form in Matsui 2017: No. 218, 1. 2. The second element of the name, $\check{s} u s a(?)$, presumably is another form of $\check{s} u t z a$ originating from Chin. shou zuo 首座, which is a Buddhist rank. However, the reading $\check{s} u s a(?)$ is not certain. It should be noted that the word following šiladu also starts with $s$ in the inscription No. 218 edited by Matsui (for details, see Matsui 2017: No. 218).

\subsection{Inscription $G$}

\section{Transcription}

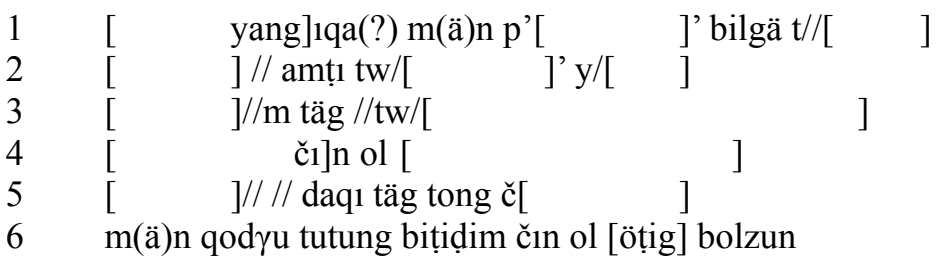

\section{Translation}

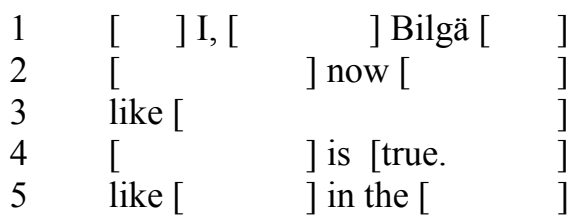

6 I, Qod $\gamma \mathrm{u}$ Tutung wrote (this), (this) is true, may it be [a memory].

\section{Commentary}

G5 täg: this word might also be read täk and seems to form a personal name, together with the following element, tong $\breve{c}[]$. In that case, it might be of Chinese origin.

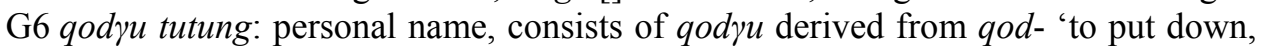
abandon, give up' (Clauson 1972: 595b) and tutung. In civil documents qod $\gamma$ occurs as a name of a tax; see SUK: 277a.

\subsection{Inscription $\mathrm{H}$}

\section{Transcription}

$1 \mathrm{~m}(\mathrm{ä}) \mathrm{n}$ singu $\mathrm{m}(\mathrm{a}) \mathrm{n}$ šilavante biz bitidimiz uẓik v[u]u bolzun

2 vuu $<$ šilavante [ ] bo[lu] $p$ 
$\begin{array}{lll}3 & \text { qulut [ ] öți[g bolzun(?) } \\ 4 & \mathrm{~m}(\ddot{a}) n[\end{array}$

\section{Translation}

1 I, Singu, (and) I, Śilavānde, we wrote (this). May the letter be a sign.

2 ' $<$ ' being the sign [of] Śilavānde [ ]

3 slave [ May it be] a memory! [ ]

4 I, [ ]

\section{Commentary}

H1 singu: personal name, it is not clear whether singu is a variant of sigu appearing in Matsui 2017: No. 160; for sigu, see Matsui 2017: 84, Note 2.

šilavante: is a common personal name in Old Uyghur, and originates from Skt. śilava(n)t via the intermediary of Tocharian B silavānde.

$\mathrm{H} 2$ vuu: goes back to Chin. $f u$ 符 which means 'mark, sign, seal', and also refers to amulet; see Zieme 2005: 231-232. $v[u] u$ in Inscription H below (line 1) was restored on the basis of this word.

\subsection{Inscription I}

1 činvašu šäli

2 bitidim

3 m(ä)n tašvardu biẓ̌

4 täẓik

[IMAGE lab ] //'

5

[IMAGE $/ / 1 / / /] \quad /$ wn w m(ä)n činvašu čizdim

\section{Translation}

$1 \quad$ I, Jivasū Šäli

2 wrote.

3 I, the monk, Tašvardu,

4 Täzik

[IMAGE candle ] //,

5

[IMAGE //1//] ] /wn w I, Činvasu, draw (this).

\section{Commentary}

I1 činvasu šäli: personal name, consists of činvasu and šäli. The same name also occurs in the form of Čivasu Šäli in Inscription O, line 1. As šäli is a copy of Chin. sheli 闍梨, a title for a high-ranking Buddhist monk, which is frequently used as a component of personal names of Buddhist clergymen or laymen in Old Uyghur texts. The other component of the name činvasu or čivasu presumably goes back to Skt. jivasü; for jivasū, see Ogiwara 1986: 506b. 
I4 täzik: occurs as an ethnic name in the texts written in Orkhon Turkic and Old Uyghur, and refers to Arabs; for details, see Yakup 2002: 416-417. This word can also be read täzig 'fleeing', 'flying', 'flight', the action noun form of the verb täz- 'disappear'; see Erdal 1991: 207.

$l a b$ : presumably, lab means 'candle', and might go back to Middle Mongolian lab 'candle' or 'light'. For Middle Mongolian lab, see Rybatzki 2006: 581b. It might also originate from Skt. lābha which has the meanings 'meeting with, finding', 'obtaining, getting, attaining, acquisition, gain, profit', etc. For Skt. lābha, see Monier-Williams 1899: 897a. lab also occurs in the same form in Matsui 2017: No. 252, 1. 2. It is also known as part of the verbal phrase lab tut- 'to give alms'; see Zieme 1981: 244 (U 5317, 1. 7).

\subsection{Inscription $J$}

\section{Transcription}

1 [ ] ay on yangıqa m(ä)n [ ] ]

\section{Translation}

1 [ ] month, on the tenth day, I [ ]

\subsection{Inscription $K$}

\section{Transcription}

1 bars y1 ikinti ay on yang1[qa] // ///

$2 \quad$ luu vu tam(?)

3 aranyatan oruntaq1 oluryučı /[ ] šila

$4 \quad$ birvu šila šilavant šila m(ä)n senqo(?)

5 äšitip turup bitiyü t[ägin]tim

6 körgü öṭig bolzun tep m(ä)n itägüy bitidim

\section{Translation}

1 Tiger year, second month, second month, on the 10th day,

2-4 [...] Śīla, Bhiru(?) Śīla, Śilavānde Śīla who sit in the temple Longfutan, and I Senqo(?)

5 ventured to write by hearing.

$6 \quad$ Hoping it may be a memory to see, I, Itägüy wrote. 


\section{Commentary}

K2 luи vu tam: presumably goes back to Chin. Longfutan 龍府壇 or Longfunan 龍府 南, and seems to be the name of the temple where three monks, [...] Sîla, Bhiru(?) Śìla and Śilavānde Śîla, sit. However, it is not clear which temple it refers to. It might refer to the cave NK 10 or the entire Tuyoq Grottoes to which the cave NK 10 belongs, if not, it might also be a temple somewhere else around Turfan or Dunhuang.

K4 birvu šila: personal name, consists of birvu, which, presumably goes back to Skt. Bhiru (Ogiwara 1986: 962a), and šila, abbreviated form of šilavanti, title for Buddhist clergymen or laymen of eminent virtue. Usually, šila is used as a component of personal names, which is also the case in this inscription. senqo(?): personal name, the fourth letter of the word is not clearly visible, therefore, the reading is not secured. Presumably, it goes back to Chin. shanguang 善光 or changuang 禅光. For the Chinese characters transcribed by means of syn, see Shōgaito et al. 2015: 185.

\subsection{Inscription $L$}

\section{Transcription}

1 qulutı to rril šilaputre

2 tägrä(?) bitidim čın ol kenki

3 körgü öțig bolzun

4 bo vrxarta m(ä)n čiz(dim) IMAGE vu IMAGE

$5 \quad / /[$ ]// m(ä)n ligui // bitiyü tägintim

\section{Translation}

1 His slave, Tơril Śilāputra

2 wrote around(?). This is true.

3 May it be a memory to be seen by (people) in future!

4 I drew (this) in the temple. IMAGE sign IMAGE

$5 \quad$ I, Li Hui, ventured to write.

\section{Commentary}

L1 toyrll šilaputre: personal name, consists of toyrll, which is also known from some Old Uyghur texts (see SUK, 292), and šilaputre originating from Skt. Śilāputra 'son of a stone' (Ogiwara 1986: 1331a).

L2 tägrä: means '(all) around' (Clauson 1972: 485b), however, the reading is not secured as the last two letters are not clearly visible.

L5 ligui: personal name, also occurs in the Berlin fragment U 5319, and originates from Chin. li hui 禮惠; for details, see Zieme 1981: 256. 


\subsection{Inscription $M$}

Transcription

$1 \quad$ qoyn y1l $b[\mathrm{i}] \mathrm{r} \mathrm{y}(\mathrm{e})$ girminč ay beš yangıqa

$2[\quad] / /[] / /$ šilavante qya bitidim

3 m(a)xa(?) IMAGE

\section{Translation}

1 Sheep year, eleventh month, fifth day,

2 [ ] I, Śilavānde Qya, wrote.

3 m(a)hā(?) IMAGE

\subsection{Inscription $N$}

\section{Transcription}

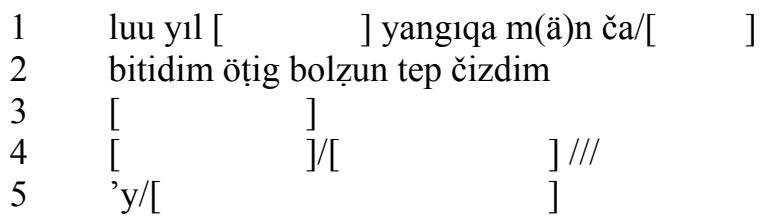

\section{Translation}

1 Dragon year, [ ] on the [ ], I, [ ]

2 wrote. I drew (this), wishing it may be a memory.

$\left.\begin{array}{lll}3 & {[} & {[}\end{array}\right]$

\subsection{Inscription $O$}

Transcription

$1 \quad$ [ ] m(ä)n čivušu šäli

2 /// vrxarta(?) m(ä)n bitidim [ ] qy,

3 [ ö]tig bolzun

\section{Translation}

1 [ ] ] I, Čivusu Šäli

2 /// in the temple (?) I wrote [ ] Qya

3 May (this) be a memory. 
Commentary

O1 čivusu šäli: presumably, this is another form of činvasu šäli and čivasu šäli occurring in Inscription I, discussed above.

\subsection{Inscription $P$}

\section{Transcription}

$\begin{array}{ll}1 & / /[\quad] / \mathrm{p} / / / / / \\ 2 & \text { yaq1n [kä]1[i]p(?) } \\ 3 & \text { bo [ ] p/////[ ] }\end{array}$

Translation

$\begin{array}{ll}1 & {[} \\ 2 & \text { coming close(?) } \\ 3 & \text { this [ ] }\end{array}$

\subsection{Inscription $Q$}

Transcription

$\begin{array}{ll}1 & \operatorname{taviš\gamma an~y1l~[~} \\ 2 & / / /[ \\ 3 & / / / /[ \\ 4 & / / / / / \\ 5 & / /\end{array}$

\section{Translation}

$\begin{array}{lll}1 & \text { Rabbit year, }[ & ] \\ 2-4 & {[}\end{array}$

\subsection{Inscription $R$}

\section{Transcription}

1 ud yıl onunč ay

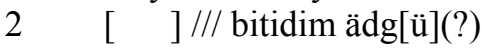

\section{Translation}

1 Ox year, tenth(?) month,

2 [ ] I wrote. Good(?)! 


\subsection{Inscription $S$}

Transcription

1 luu y1l äräm ay iki [y(e)]girmi[kä] m(ä)n tayanč

2 šäli bitidim ö[tig] b[olz]un(?)

\section{Translation}

1 Dragon year, first month, on the twelfth day, I, Tayanč

2 Šäli wrote. May (this) be a memory!

\subsection{Inscription $T$}

Transcription

1 taq1(?)

2 bolẓun y11(?)

3 ymä(?)

4 öțig

5 bolzun

\section{Translation}

$\begin{array}{ll}1 & {[\text { May (this) be }] \text { year }} \\ 2 & \text { Again(?) } \\ 4-5 & \text { May (this) be a memory! }\end{array}$

\section{Acknowledgements}

This paper presents part of the research carried out within the framework of the Specially Funded Research Projects 'Etymological Investigations on the Turkic Languages in China' (Founding No. 11\& ZD 130) and 'Research on the Cave Monasteries in Xinjiang' (Founding No. 14\& ZDB 054), supported by the National Social Sciences Foundation of China.

\section{References}

BAI Yudong 白玉冬 and MATSUI Dai 松井太 2016. 'Huhuhoto hakutō no uigurugo daiki meibun フフホト白塔のウイグル語題記銘文 [Old Uigur inscriptions of the White Pagoda, Hohhot].' Nairiku Ajia gengo no kenkyū 内陸アジア言語の研究 / Studies on the Inner Asian Languages 31: 29-77. 
CHEN Ling 陈凌, LI Yuqun 李裕群 and LI Xiao 李肖 2012a. 'Xinjiang Shanshan xian Tuyugou dongqu beice shiku fajue jianbao 新疆部善县吐峪沟东区北侧石窟发掘简报 [A survey of the excavation carried out in the eastern portion in the Tuyoq Grottoes in Pichan County of Xinjiang].' Kaogu 考古 1: 7-16+6 plates.

CHEN Ling 陈凌, LI Yuqun 李裕群 and Li Xiao 李肖 2012b. 'Xinjiang Shanshan xian Tuyugou xiqu beice shiku fajue jianbao 新疆鄯善县吐峪沟西区北侧石窟发掘简报 [A survey of the excavation carried out in the northern portion in the Tuyoq Grottoes in Pichan County of Xinjiang].' Kaogu 考古 1: 17-22+12 plates.

Clauson, Gerard 1972. An Etymological Dictionary of Pre-Thirteenth-Century Turkish. Oxford: Clarendon Press.

ERDAL, Marcel 1991. Old Turkic Word Formation. A Functional Approach to the Lexicon. [Turcologica 7.] 1-2 vols. Wiesbaden: Otto Harrassowitz.

Hamilton, James and NiU Ruji 1998. 'Inscriptions ouïgoures des grottes bouddhiques de Yulin.' Journal Asiatique 286: 127-210.

KARA, G[yörgy] 1976. 'Petites inscriptions ouigoures de Touen-houang.' In: Gy[ula] KÁLDY-NAGY (ed.) Hungaro-Turcica. Studies in Honour of Julius Németh. Budapest: Loránd Eötvös University, 55-59.

KITSUDŌ Kōichi 橘堂晃一 2017. 'Tonkō sekkutsu Burahumimoji daiki meibun shūsei 敦煌石窟 ブラーフミ文字題記銘文集成 [Brāhmī inscriptions of the Dunhuang Grottoes].’ In: Matsui and Arakawa 2017: 163-198.

LE CoQ, Albert von 1913. Chotscho. Facsimile-Wiedergaben der wichtigeren Funde der ersten Königlich Preußischen Expedition nach Turfan in Ost-Turkistan. Berlin: Dietrich Reimer und Ernst Vohsen.

LE CoQ, Albert von 1922-1926. Die buddhistische Spätantike in Mittelasien. Ergebnisse der Königlich Preußischen Turfan-Expeditionen. I-VI. Berlin: Dietrich Reimer und Ernst Vohsen.

Li Xiao 李肖 2015. 'Jinnian Tulufan fojiao shikusi kaogu de xin shouhuo 近年吐鲁番石窟寺考古 的新收获 [New discoveries of archaeological investigations in the Buddhist caves in Turfan].' In: Abdurishid Yakup (ed.) Studies in Central Asian Philology, Papers of the International Symposium on Central Asian Philology, November 2012, Beijing. Shanghai: Shanghai Chinese Classics Publishing House, 138-160.

Li Yuqun 李裕群, Li Xiao 李肖 and CHEN Ling 陈凌 2011. 'Tuyugou shiku de xin faxian: yingxiang Tulufan lishi de fojiao yizhi 吐峪沟石窟的新发现：影响吐鲁番历史的佛教遗址 [The new discovery of Tuyoq Grottoes: The Buddhist temple relics with significant influence on the history of Turfan].' Zhongguo Wenhua Yichan 中国文化遗产 2: 66-73.

MATSUI Dai 松井太 2008. 'Revising the Uigur inscriptions of the Yulin caves.' Nairiku Ajia gengo no kenkyū 内陸アジア言語の研究 Studies on the Inner Asian Languages 23: 17-32.

MATSUI Dai 松井太 2015. 'Dunhuang Mogaoku Anxi Yulinku de Huihuyu tiji 敦煌莫高窟安西榆 林窟的回鶻語題記 [Old Uigur inscriptions of the Anxi Yulin caves in the Mogao caves].' In: Abdurishid YakuP (ed.) Studies in Central Asian Philology, Papers of the International Symposium on Central Asian Philology, November 2012, Beijing. Shanghai: Shanghai Chinese Classics Publishing House, 210-225.

MATSUI Dai 松井太 2017. 'ta gengo sekkutsu uigurugo mongorugo daiki meibun shūsei 敦煌石窟 ウイグル語・モンゴル語題記銘文集成 [Uigur and Mongol inscriptions of the Dunhuang Grottoes].' In: MATSUI and ARAKAWA 2017: 1-160 + Figures 1, 3-7.

MATSUI Dai 松井太 and ARAKAWA Shintarō 荒川慎太郎 (eds.) 2017. Tonkō sekkutsu ta gengo shi$r y \bar{o}$ shūsei 敦煌石窟多言語資料集成 [English title: Multilingual source materials of the Dunhuang Grottoes]. Fuchu (Tokyo): Tokyo University of Foreign Studies. 
Maue, Dieter 1996. Alttürkische Handschriften. Teil 19: Dokumente in Brāhmī und tibetischer Schrift. Teil 1. [Verzeichnis der Orientalischen Handschriften in Deutschland, Bd. 13,9.] Stuttgart: Franz Steiner Verlag.

MaUE, Dieter 2015. Alttürkische Handschriften. Teil 19: Dokumente in Brāhmī und tibetischer Schrift. Teil 2. [Verzeichnis der Orientalischen Handschriften in Deutschland, Bd. 13,27.] Stuttgart: Franz Steiner Verlag.

Monier-Williams, Monier (1899). A Sanskrit-English Dictionary. Etymologically and Philologically Arranged with Special Reference to Cognate Indo-European Languages. (New edition, greatly enlarged and improved.) Oxford: Clarendon Press.

MorIYASU, Takao 2008. 'Chronology of West Uighur Buddhism: Re-examination of the Dating of the Wall-paintings in Grünwedel's Cave No. 8 (New: No. 18), Bezeklik.' In: Peter ZIEME (ed.) Aspects of Research into Central Asian Buddhism. In Memoriam Kögi Kudara. [Silk Road Studies 16.] Turnhout: Brepols, 191-227.

ODA Juten 小田壽典 1987. 'Uiguru no shōgō tutung to sono shūhen ウィグルの称号トウトゥ ンッとその周辺 [On the title Tutung in Uighur].' Tōyō-shi kenkyū 東洋史研究 46/1: 5786.

OGIWARA Unrai 荻原雲来 1986. Kanyaku taisho bon-wa daijiten 漢訳対照梵和大辞典 [A Sanskrit-Japanese dictionary with equivalent in Chinese translation]. Tokyo: Sankibo Buddhist Book Store (new edition).

Pelliot, Paul 1922-1924. Les Grottes de Touen-houang: Peintures et sculptures bouddhiques des époques des Wei, des Tang et des Song. 6 vols. Paris: Geuthner.

Pelliot, Paul, Monique Maillard et Nicole VANDier-NiCOlas 1981-1992. Les Grottes de Touenhouang: Carnet de notes de Paul Pelliot: Inscriptions et peintures murales. 6 vols. Paris: Collège de France / Instituts d'Asie / Centre de recherche sur l'Asie centrale et la Haute Asie.

Porció, Tibor 2014. 'Some Peculiarities of the Uyghur Buddhist Pilgrim Inscriptions.' In: Christoph CuepPers and Max DeEg (eds.) Searching for the Dharma, Finding Salvation-Buddhist Pilgrimage in Time and Space: Proceedings of the Workshop "Buddhist Pilgrimage in History and Present Times" at the Lumbini International Research Institute, Lumbini, 11-13 January 2010. Lumbini: Lumbini International Research Institute, 157-178.

RyBATZKI, Volker 2006. Die Personennamen und Titel der mittelmongolischen Dokumente. Eine lexikalische Untersuchung. [Publications of the Institute for Asian and African Studies 8.] Helsinki: Yliopistopaino Oy.

Shōgaito, Masahiro, Setsu Fujishiro, Noriko OhSAKi and Mutsumi Sugahara 2015. The Berlin Chinese Text U 5335 Written in Uighur Script. A Reconstruction of the Inherited Uighur Pronunciation of Chinese. [Berliner Turfantexte XXXIV.] Turnhout: Brepols.

SUK = Yamada 1993.

YAKUP, Abdurishid 2002. 'On the Interlinear Uighur Poetry in the Newly Unearthed Nestorian Text.' In: Simone-Christiane RASCHMANN and Mehmet ÖLMEZ (eds.) Splitter aus der Gegend von Turfan: Festschrift für Peter Zieme anlässlich seines 60. Geburtstags. Berlin und Istanbul: Şafak Matbaacılık, 409-417.

YAKUP, Abdurishid and Li Xiao 2018. 'An Old Uyghur Text Written on a Wooden Plate Recently Discovered in the Tuyoq Grottoes in Turfan.' AOH 71/3: 303-317.

YAMADA Nobuo 1993. Uigurubun keiyaku monjo shūsei ウイグル文契約文書集成 [German title: Sammlung uigurischer Kontrakte]. 1-3. Edited by Juten OdA, Peter ZIEME, Hiroshi UmEMURA and Takao MORIYASU. Osaka: Osaka University Press.

ZIEME, Peter 1981. 'Uigurische Steuerbefreiungsurkunden für buddhistische Klöster.' Altorientalische Forschungen 8: 237-263. 
ZIEME, Peter 1985. Buddhistische Stabreimdichtungen der Uiguren. [Berliner Turfantexte XIII.] Berlin: Akademie Verlag.

ZIEME, Peter 1987. 'Materialien zum uigurischen Onomasticon III.' Türk Dili Araştırmaları Yılliğg Belleten 1984 [1987]: 267-283.

ZIEME, Peter 2005. Magische Texte des uigurischen Buddhismus. [Berliner Turfantexte XXIII.] Turnhout: Brepols.

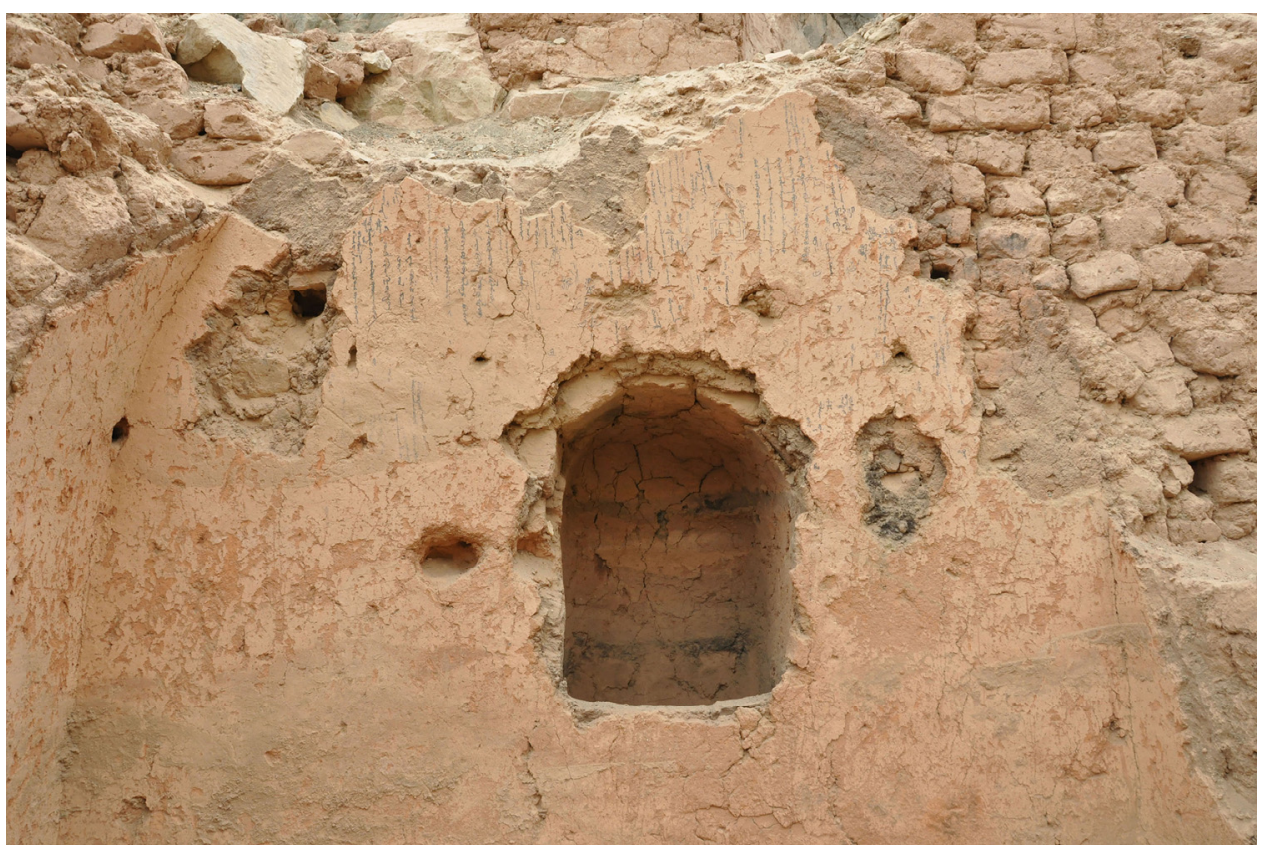

Old Uyghur pilgrim inscriptions discovered in NK10 in the Tuyoq Grottoes, Turfan, China 

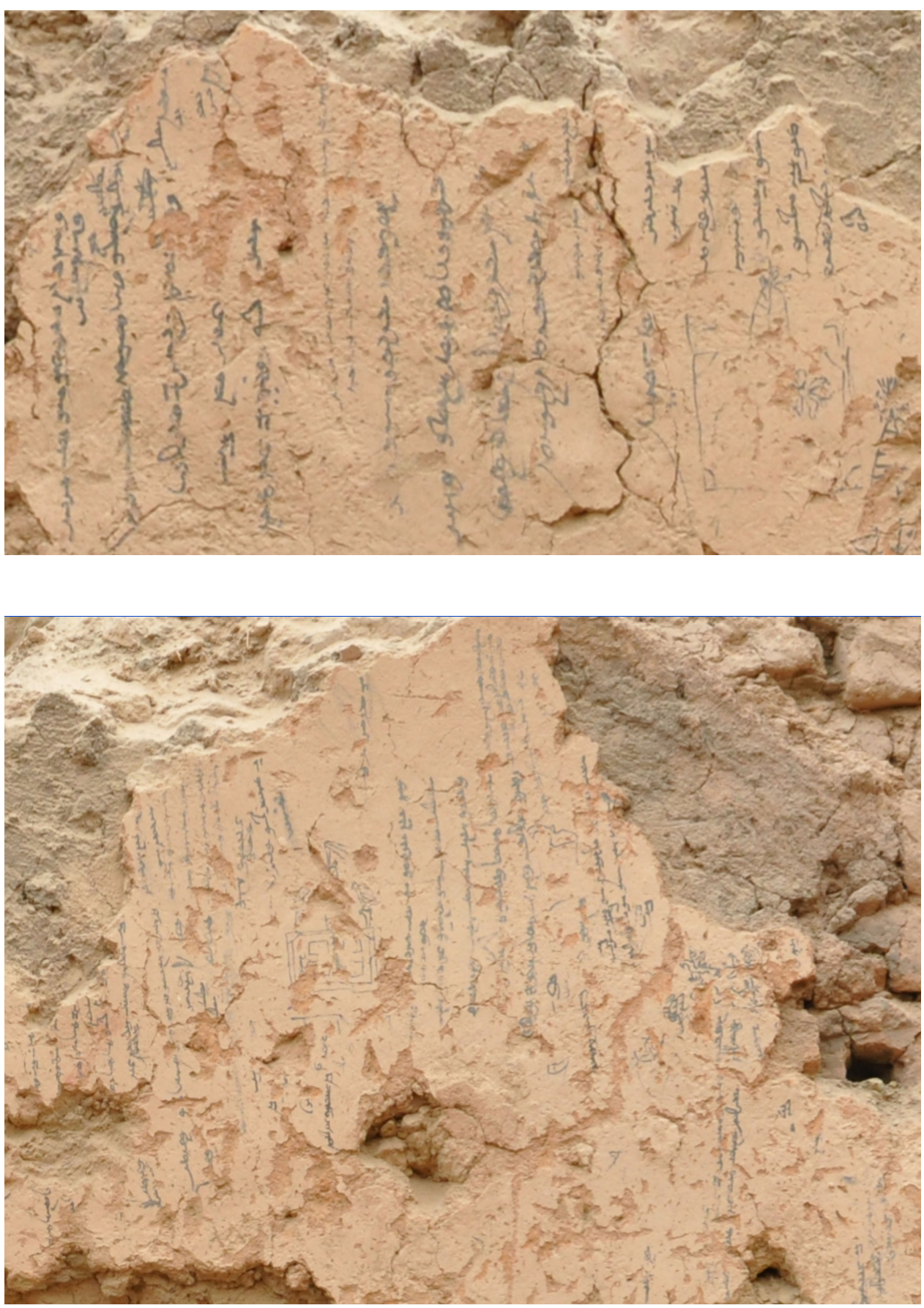

Old Uyghur pilgrim inscriptions discovered in NK10 enlarged 
